\title{
Association of C-Reactive Protein and Metabolic Disorder in a Chinese Population
}

\author{
Mingxia Sun ${ }^{1,2}$, Liying Zhang ${ }^{1,3}$, Shanying Chen ${ }^{1,4}$, Xinyu Liu ${ }^{1}$, Xiaofei Shao ${ }^{1}$ \\ and Hequn Zou ${ }^{1, *}$
}

1 Department of Nephrology, The Third Affiliated Hospital of Southern Medical University, Guangzhou, Guangdong 510630, China; E-Mails: feixia_97@163.com (M.S.); zhangliying926@126.com (L.Z.); dqydqy386@sina.com (S.C.); pepsi84@163.com (X.L.); shaoxfei@126.com (X.S.)

2 Department of Nephrology, Huhhot First Hospital, Huhhot, Inner Mongolia 010010, China

3 Department of Nephrology, The First Affiliated Hospital of Inner Mongolia Medical University, Huhhot, Inner Mongolia 010010, China

4 Department of Nephrology, Zhangzhou Affiliated Hospital of Fujian Medical University, Zhangzhou, Fujian 363000, China

* Author to whom correspondence should be addressed; E-Mail: hequnzou@hotmail.com; Tel./Fax: +861-20-6278-4203.

Academic Editor: Paul B. Tchounwou

Received: 3 May 2015 / Accepted: 30 June 2015 / Published: 17 July 2015

\begin{abstract}
Objective: To assess the high-sensitivity C-reactive protein (hs-CRP) levels and explore the risk factors for an elevated hs-CRP level. We also provide the clinical utility of CRP to identify subjects with metabolic syndrome (MetS). Methods: Data were drawn from a cross-sectional survey in China. Subjects were divided into three subgroups: hs-CRP $\leq 1 \mathrm{mg} / \mathrm{L}, 1 \mathrm{mg} / \mathrm{L}<\mathrm{hs}-\mathrm{CRP} \leq 3 \mathrm{mg} / \mathrm{L}$ and hs-CRP $>3 \mathrm{mg} / \mathrm{L}$. Multiple linear regressions and logistic regression models were used. Results: In the Chinese population, $50.43 \%$ subjects had a low hs-CRP level, 30.21\% subjects had an intermediate hs-CRP level and $19.36 \%$ subjects had an elevated hs-CRP level. Age, physical inactivity, abdominal obesity, a low LDL level, an elevated fasting glucose level, uric acid and urinary albumin to creatinine ratio (ACR) were correlated with log-CRP. In multivariate analysis, relative risks of an elevated CRP level were 2.40 (95\% CI 1.44-3.99, $p=0.001$ ), 3.63 (95\% CI 2.20-5.98, $p<0.001), 4.23$ (95\% CI 2.51-7.11, $p<0.001)$ and $6.23(95 \% \mathrm{CI}$ $3.45-11.26, p<0.001$ ) for subjects with $1,2,3$, or more than 3 MetS components,
\end{abstract}


respectively. The accurate estimates of the area under the receiver operating characteristic of hs-CRP for MetS was 0.6954 (95\% CI, 0.67-0.72). Conclusion: Age, physical inactivity, abdominal obesity, a low LDL level, an elevated fasting glucose level, uric acid and ACR are correlated with log-CRP. The number of MetS components is a significant determinant of elevated CRP levels after adjusted for other potential confounders.

Keywords: C-reactive protein; metabolic disorder

\section{Introduction}

According to the findings from the Global Burden of Disease Study 2010, cardiovascular disease (CVD) is the leading cause of death in China [1]. Hypertension, diabetes, dyslipidemia, older age, male sex and smoking are well known CVD risk factors [2,3]. Evaluation of CVD risk factors and early intervention might contribute to lower mortality from CVD. In addition, C-reactive protein (CRP), one acute-phase protein correlated with inflammation, has been considered as a novel risk factor of CVD [2]. Several prospective studies have demonstrated that high-sensitivity CRP (hs-CRP) independently predicts vascular events and adds predictive value to the Framingham Risk Score [2]. It is also found that hs-CRP levels are correlated with metabolic syndrome (MetS) [4-11], and endothelial dysfunction [12].

Based on this evidence, the CDC-AHA Writing Group recommended the optional use of hs-CRP testing in patients with 10-year Framingham coronary heart disease (CHD) risk between 10\% and $20 \%$ [13]. It is recommended that a hs-CRP level of less than $1.0 \mathrm{mg} / \mathrm{L}$ is considered to denote low risk, 1.0 to $3.0 \mathrm{mg} / \mathrm{L}$ intermediate risk, and greater than $3.0 \mathrm{mg} / \mathrm{L}$ high risk $[14,15]$. CRP is also proposed as one component of MetS [4,16]. However, previous studies are based on western countries. One previous study [3] based on a Japanese population suggested that a tentative cut point of hs-CRP as a component of MetS might be $0.45 \mathrm{mg} / \mathrm{L}$ in men and $0.25 \mathrm{mg} / \mathrm{L}$ in women. The results indicated the ethnic differences in the CRP levels [3]. There may also be ethnic differences in the clinical utility of CRP. As we know, there are relatively limited data on CRP in Chinese individuals. In our previous study, the result indicated that obesity is associated with the level of CRP, but the associations of other metabolic disorders and the level of CRP were not reported in the study [16]. In this previous study, we have assessed an elevated level of CRP in the obese and non-obese subgroups, however, the data of a low level and an intermediate level of CRP were not applied [16]. We carried the present study to assess the CRP levels in a Chinese population and explore the risk factors of an elevated CRP level. We also provide the clinical utility of CRP to identify men and women with MetS.

\section{Experimental Section}

\subsection{Ethics Statement}

This study was approved by the ethics committee of the Third Affiliated Hospital of Southern Medical University. All subjects gave their written informed consent. This study was supported by the following Science Foundation: (1) EU FP7 Program, UroSense, 2011; (2) ISN Research Committee 
grant, 2007; (3) ISN Research Committee grant, 2004; (4) Guangdong Provincial Science and Technique Program (No. 2011B031800386), 2011.

\subsection{Study Population}

We used the database drawn from one cross-sectional survey which was conducted in Wanzhai Town, Zhuhai City, China. This survey was performed from June 2012 to October 2012. Finally, 2142 residents (aged 18 years or older) completed the survey. A total of 308 subjects were excluded because of missing data. A total of 1843 subjects were included in the present analyses. We have described the survey in previous article [17].

\subsection{Data Collection}

Data on socio-demographic status, personal and family health history and lifestyle habits were obtained through questionnaires. History of drug use was also obtained by questionnaires. Systolic blood pressure (SBP) and diastolic blood pressure (DBP) were determined on the right arm in a seated position using a calibrated mercury sphygmomanometer. Before blood pressures were determined, all of the subjects rested for at least $5 \mathrm{~min}$. Blood pressures were determined consecutively three times and the average of the three readings was calculated [17]. Waist circumference was measured according to the World Health Organization recommended protocols [18].

\subsection{Determination of $C R P$}

High sensitivity C-reactive protein (hs-CRP) was determined using an enzymatic immunoassay turbidimetric method (reagent: Orion, Finnish; apparatus: Roche Cobas 6000, Penzberg, Germany). After an overnight fasting for at least $10 \mathrm{~h}$, blood specimens were collected. All blood specimens were analyzed in the central laboratory of Third Affiliated Hospital of Southern Medical University [17]. According to the previous guideline, a hs-CRP level of less than $1.0 \mathrm{mg} / \mathrm{L}$ is considered to a low level, 1.0 to $3.0 \mathrm{mg} / \mathrm{L}$ an intermediate level, and greater than $3.0 \mathrm{mg} / \mathrm{L}$ an elevated high risk $[14,15]$.

\subsection{Metabolic Disorder}

According to Third Report of the National Cholesterol Education Program (NCEP) Expert Panel, MetS was defined as having at least three of the five components: abdominal obesity, elevated triglyceride levels $(\geq 150 \mathrm{mg} / \mathrm{dL})$, low high density lipoprotein cholesterol levels $(<40 \mathrm{mg} / \mathrm{dL}$ in men, or $<50 \mathrm{mg} / \mathrm{dL}$ in women), an elevated blood pressure $(\geq 130 / 85 \mathrm{mmHg}$ ) and an elevated fasting glucose level $(\geq 6.1 \mathrm{mmol} / \mathrm{L})$ [19]. Abdominal obesity was modified for Chinese as $>90 \mathrm{~cm}$ for men and $>80 \mathrm{~cm}$ for women based on the definition of MetS by International Diabetes Federal [20]. Hyperuricemia was defined as serum uric acid $\geq 7 \mathrm{mg} / \mathrm{dL}$ in men or $\geq 6 \mathrm{mg} / \mathrm{dL}$ in women $[21,22]$. Albuminuria is also an independent predictor of CVD in both men and women [23]. Albuminuria was defined as urinary albumin to creatinine ratio (ACR, $\mathrm{mg} / \mathrm{g}$ ) $\geq 30 \mathrm{mg} / \mathrm{g}$ [24]. Urinary albumin to creatinine ratio $(\mathrm{ACR}, \mathrm{mg} / \mathrm{g}$ ) was calculated as the ratio of urinary albumin to urinary creatitine. Serum creatinine, serum fasting glucose, serum total cholesterol, serum triglyceride, serum high-density lipoprotein cholesterol (HDL), serum low-density lipoprotein cholesterol (LDL) and urinary 
creatitine were determined using colorimetric methods. Serum insulin was determined using electrochemiluminescence immunoassays. Urinary albumin was measured by an immune nephelometric method [17].

Homeostatic model assessment of insulin resistance (HOMA-IR) was calculated as fasting plasma glucose $(\mathrm{mmlo} / \mathrm{L}) \times$ fasting insulin $(\mathrm{mU} / \mathrm{L}) / 22.5$ [25]. Insulin resistance was defined as HOMA-IR $>2.69$ (exceeding the $75 \%$ percentile of HOMA-IR in normal glucose tolerance subjects) [26].

\subsection{Data Analysis}

Using Stata (version 11) for data analysis, 1834 subjects were included in the analysis. Continuous variables were reported as mean and standard deviation or median values and interquartile range as appropriate. Categorical data were presented by frequencies and percentages. Based on the levels of hs-CRP, participants were divided into three subgroups for all analyses: participants with a low level of hs-CRP (hs-CRP $\leq 1 \mathrm{mg} / \mathrm{L}$ ); participants with an intermediate CRP level (hs-CRP $>1 \mathrm{mg} / \mathrm{L}$ and hs-CRP $\leq 3 \mathrm{mg} / \mathrm{L}$ ); participants with en elevated CRP level (hs-CRP $>3 \mathrm{mg} / \mathrm{L}$ ). One-way Analysis of Variance, or the Kruskal-Wallis test, was used to analyze the differences in clinical characteristics for three subgroups if the variables were continuous variables. A Bonferroni's adjustment was used for the effect of the multiple comparisons. The chi-squared test or Fisher's exact test was used to compare categorical variables.

In order to examine the risk factors associated with hs-CRP, multiple linear regressions were used. High sensitivity C-reactive protein was used as an independent variable. All variables with skewed distributions were logarithmically transformed before being analyzed. These variables included hs-CRP, serum triglyceride and ACR. Firstly, variables were examined in unadjusted models. These variables included: socio-demographic characteristics (age, sex, and education attainment), comorbidities (history of coronary heart disease, and history of stroke), lifestyle factors (current smoker, current alcohol use, and physical inactivity), components of MetS, serum uric acid and ACR. Next all of these variables were examined in the adjusted model. Only eight subjects were taking statin, so taking statin was not added into the adjusted model.

We also examined the associations of the level of CRP with the number of MetS components present $(0,1,2,3$, and more than 3$)$. An elevated CRP level was defined as the hs-CRP level $>3 \mathrm{mg} / \mathrm{L}$. Logistic regression models were used and adjusted for the covariates used in the above regression models. Subjects with 0 component of MetS were designated as the reference subgroup.

Accurate estimates of the area under the receiver operating characteristic (AUROC) curve analysis was performed by using the level of CRP for diagnosing MetS. An AUROC $\geq 0.7$ was considered as acceptable [27]. Youden's index was used to select the optimal cut-offs for the level of CRP. Youden's index was calculated as (specificity + sensitivity -1$)$. 


\section{Results and Discussion}

\subsection{Baseline Characteristics (Table 1)}

Baseline characteristics of the subjects are presented in the Table 1.1834 subjects (the mean age was $52.8 \pm 14.5$ years and 679 were men) were included in the analysis. The median hs-CRP was $0.99 \mathrm{mg} / \mathrm{L}$ (interquartile range, $0.46-2.37 \mathrm{mg} / \mathrm{L}$ ) in the total population. The median hs-CRP was $1.01 \mathrm{mg} / \mathrm{L}$ (interquartile range, $0.49-2.63 \mathrm{mg} / \mathrm{L}$ ) in men and $0.98 \mathrm{mg} / \mathrm{L}$ (interquartile range, $0.44-2.25 \mathrm{mg} / \mathrm{L}$ ) in women, respectively [28]. There was no significantly difference in CRP between men and women $(p=0.17$, not shown in the table) [28].

Table 1. Characteristics of subjects according to the level of C-reactive protein.

\begin{tabular}{|c|c|c|c|c|}
\hline Clinical Characteristics & $\begin{array}{c}\text { Group 1 } \\
\text { CRP } \leq 1 \mathrm{mg} / \mathrm{L} \\
\mathrm{N}=925 \\
\end{array}$ & $\begin{array}{c}\text { Group 2 } \\
1 \mathrm{mg} / \mathrm{L}<\mathrm{CRP} \leq 3 \mathrm{mg} / \mathrm{L} \\
\mathrm{N}=\mathbf{5 5 4}\end{array}$ & $\begin{array}{c}\text { Group } 3 \\
\text { CRP }>3 \mathrm{mg} / \mathrm{L} \\
\mathrm{N}=355 \\
\end{array}$ & $p$ Value \\
\hline C-reactive protein & $0.47(0.28-0.69)$ & $1.69(1.29-2.19)$ & $5.18(3.73-8.31)$ & $<0.001$ \\
\hline Age (Years) & $50.02 \pm 14.71$ & $54.87 \pm 13.65$ & $56.67 \pm 13.87$ & $<0.001$ \\
\hline Male (\%) & $338(36.5)$ & $198(35.9)$ & $142(40.1)$ & 0.42 \\
\hline History of diabetes mellitus (\%) & $44(4.8)$ & $38(6.9)$ & $33(9.3)$ & $<0.001$ \\
\hline History of hypertension (\%) & $127(13.8)$ & $145(26.3)$ & $100(28.1)$ & $<0.001$ \\
\hline History of stroke (\%) & $3(0.3)$ & $2(0.4)$ & $2(0.6)$ & 0.78 \\
\hline $\begin{array}{l}\text { History of coronary heart disease } \\
\text { (\%) }\end{array}$ & $19(2.1)$ & $10(1.8)$ & $13(3.7)$ & 0.16 \\
\hline Current smoker (\%) & $93(10.3)$ & $76(13.8)$ & $54(15.3)$ & 0.02 \\
\hline Current alcohol use (\%) & $45(4.9)$ & $38(6.9)$ & $23(6.4)$ & 0.23 \\
\hline High school or above (\%) & $448(48.4)$ & $197(35.7)$ & $116(32.46)$ & $<0.001$ \\
\hline Physical inactivity (\%) & $502(54.27)$ & $320(57.8)$ & $191(53.8)$ & 0.36 \\
\hline Systolic blood pressure (mmHg) & $124.16 \pm 18.47$ & $131.95 \pm 20.82$ & $134.93 \pm 21.15$ & 0.001 \\
\hline Diastolic blood pressure $(\mathrm{mmHg})$ & $76.17 \pm 10.61$ & $79.40 \pm 11.01$ & $80.70 \pm 10.71$ & $<0.001$ \\
\hline Waist circumference $(\mathrm{cm})$ & $79.24 \pm 9.27$ & $85.89 \pm 9.16$ & $88.27 \pm 9.42$ & $<0.001$ \\
\hline \multicolumn{5}{|l|}{ Laboratory values } \\
\hline Fasting glucose $(\mathrm{mmo} / \mathrm{L})$ & $4.84 \pm 0.92$ & $5.09 \pm 1.27$ & $5.35 \pm 1.53$ & $<0.001$ \\
\hline Serum triglyceride $(\mathrm{mmol} / \mathrm{L})$ & $1.08(0.79-1.55)$ & $1.37(0.96-2.05)$ & $1.43(1.02-2.22)$ & $<0.001$ \\
\hline $\begin{array}{l}\text { Serum low density lipoprotein } \\
\qquad(\mathrm{mmol} / \mathrm{L})\end{array}$ & $3.03 \pm 0.86$ & $3.31 \pm 0.93$ & $3.34 \pm 0.93$ & 0.048 \\
\hline $\begin{array}{l}\text { Serum high density lipoprotein } \\
\qquad(\mathrm{mmol} / \mathrm{L})\end{array}$ & $1.58 \pm 0.33$ & $1.51 \pm 0.32$ & $1.45 \pm 0.32$ & 0.47 \\
\hline HOMA-index (uU/mL) & $1.57(1.07-2.29)$ & $1.98(1.34-3.17)$ & $2.39(1.48-3.85)$ & $<0.001$ \\
\hline $\begin{array}{l}\text { Urine albumin-to-creatinine ratio } \\
\qquad(\mathrm{mg} / \mathrm{g})\end{array}$ & $7.96(5.48-12.20)$ & $8.75(6.01-16.18)$ & $10.25(6.72-20.33)$ & $<0.001$ \\
\hline Serum uric acid (umol/L) & $333.22 \pm 88.99$ & $361.33 \pm 92.22$ & $382.10 \pm 105.59$ & 0.001 \\
\hline Serum Creatitine (umol/L) & $72.38 \pm 15.78$ & $73.41 \pm 15.64$ & $74.69 \pm 19.33$ & 0.07 \\
\hline
\end{tabular}

Mean \pm SD or median (25th to 75 th percentiles) for continuous variables and proportion (95\% confidence interval) for category variables are presented. 
Of the subjects, 50.43\% (925) had a low level of hs-CRP, 30.21\% (554) subjects had an intermediate hs-CRP level and 19.36\% (355) subjects had an elevated hs-CRP level. Eight subjects were receiving statin therapy and no subject was taking glucocorticoid. No subjects had a history of autoimmune disease. Subjects with a higher level of hs-CRP were older. They also had significantly higher levels of serum triglyceride, serum LDL, HOMA-index, ACR, serum uric acid, serum fasting glucose, higher systolic blood pressure and larger waist circumferences. They had higher proportions of history of hypertension and diabetes. These differences were significant $(p<0.05)$. Compared with the subjects with a low level of hs-CRP, subjects with an intermediate level of hs-CRP had significantly higher levels of serum triglyceride, serum LDL, HOMA-index, ACR, serum uric acid, serum fasting glucose, higher systolic blood pressure and larger waist circumferences $(p<0.05$, not shown in the table). The differences in HDL and serum creatitine among three subgroups were not significant.

\subsection{Prevalence of Metabolic Disorders according to C-reactive Protein Categories (Table 2)}

Subjects with a higher level of CRP had significant higher prevalence of metabolic disorders including components of MetS, IR, hyperuricemia and ACR.

Table 2. Prevalence of metabolic disorders according to C-reactive protein categories.

\begin{tabular}{|c|c|c|c|c|}
\hline $\begin{array}{c}\text { Metabolic disorder } \\
\text { \% (95\% CI) }\end{array}$ & $\begin{array}{c}\text { Group 1 } \\
\text { CRP }<1 \mathrm{mg} / \mathrm{L} \\
\mathrm{N}=925 \\
\end{array}$ & $\begin{array}{c}\text { Group } 2 \\
1 \mathrm{mg} / \mathrm{L}<\mathrm{CRP}<3 \mathrm{mg} / \mathrm{L} \\
\mathrm{N}=\mathbf{5 5 4}\end{array}$ & $\begin{array}{c}\text { Group } 3 \\
\text { CRP }>3 \mathrm{mg} / \mathrm{L} \\
\mathbf{N}=355 \\
\end{array}$ & $p$ Value \\
\hline Metabolic syndrome & $14.81(12.52-17.10)$ & $33.75(29.80-37.70)$ & $41.97(36.81-47.13)$ & $<0.001$ \\
\hline Insulin resistance & $15.78(13.43-18.14)$ & $33.21(29.28-37.15)$ & $44.51(39.31-49.70)$ & $<0.001$ \\
\hline Hypertension & $32.11(29.09-35.20)$ & $48.01(43.84-52.19)$ & $56.90(51.73-62.08)$ & $<0.001$ \\
\hline Diabetes & $5.84(4.32-7.35)$ & $9.21(6.79-11.66)$ & $12.96(9.44-16.47)$ & $<0.001$ \\
\hline An elevated blood pressure & $53.19(49.97-56.41)$ & $68.05(64.16-71.94)$ & $75.49(71.00-79.99)$ & $<0.001$ \\
\hline ACR & $7.35(5.67-9.04)$ & $13.18(10.35-16.00)$ & $18.31(14.27-22.35)$ & $<0.001$ \\
\hline Low HDL levels & $9.08(7.23-10.94)$ & $11.19(8.59-13.82)$ & $17.18(13.24-21.13)$ & $<0.001$ \\
\hline $\begin{array}{c}\text { An elevated fasting } \\
\text { glucose level }\end{array}$ & $9.84(7.92-11.76)$ & $18.72(15.51-22.03)$ & $23.81(19.37-28.15)$ & $<0.001$ \\
\hline Hyperuricemia & $24.43(21.66-27.21)$ & $36.23(32.21-40.25)$ & $45.94(40.74-51.13)$ & $<0.001$ \\
\hline Abdominal obesity & $32.54(29.52-35.57)$ & $61.37(57.30-65.43)$ & $70.15(65.36-74.92)$ & $<0.001$ \\
\hline Elevated triglyceride levels & $20.22(17.62-22.81)$ & $34.16(30.16-38.07)$ & $39.44(34.33-44.55)$ & $<0.001$ \\
\hline
\end{tabular}

\subsection{Correlation of Log-CRP Levels with Clinical Characteristics and Metabolic Disorders (Table 3)}

The distribution of CRP levels in this population was skewed to the right. Univariate regression models showed that age, history of coronary heart disease, smoking, alcohol use, education attainment, ACR and uric acid were correlated with the level of log-CRP. All of the components of MetS were positively correlated with log-CRP levels in univariate regression analysis. In the adjusted regression model, age and physical inactivity were still correlated with the level of log-CRP. Among the five components of MetS, abdominal obesity, low LDL levels, and an elevated fasting glucose level were 
correlated with the level of log-CRP. ACR and uric acid were also correlated with the level of $\log$-CRP.

Table 3. Correlation of log-CRP levels with clinical characteristics and metabolic disorders.

\begin{tabular}{|c|c|c|c|c|}
\hline \multirow[b]{2}{*}{ Variable } & \multicolumn{2}{|l|}{ Unadjusted } & \multicolumn{2}{|l|}{ Adjusted } \\
\hline & $\begin{array}{c}\text { Linear Regression } \\
\text { Coefficient (SE) }(95 \% \text { CI) }\end{array}$ & $p$ Value & $\begin{array}{c}\text { Linear Regression } \\
\text { Coefficient (SE) }(95 \% \text { CI) }\end{array}$ & $p$ Value \\
\hline Age & $\begin{array}{c}0.02 \\
(0.02-0.02) \\
\end{array}$ & $<0.001$ & $\begin{array}{c}0.008 \\
(0.004-0.012) \\
\end{array}$ & $<0.001$ \\
\hline Male & $\begin{array}{c}0.09 \\
(-0.02-0.20) \\
\end{array}$ & 0.10 & $\begin{array}{c}0.004 \\
(-0.13-0.14) \\
\end{array}$ & 0.96 \\
\hline $\begin{array}{c}\text { History of coronary heart } \\
\text { disease }\end{array}$ & $\begin{array}{c}0.40 \\
(0.04-0.75)\end{array}$ & 0.03 & $\begin{array}{c}0.13 \\
(-0.19-0.46)\end{array}$ & 0.41 \\
\hline History of stroke & $\begin{array}{c}0.31 \\
(-0.54-1.16)\end{array}$ & 0.48 & $\begin{array}{c}-0.09 \\
(-0.86-0.67)\end{array}$ & 0.81 \\
\hline Physical inactivity & $\begin{array}{c}0.01 \\
(-0.10-0.12) \\
\end{array}$ & 0.86 & $\begin{array}{c}0.14 \\
(0.04-0.24) \\
\end{array}$ & 0.008 \\
\hline $\begin{array}{l}\text { Education attainment } \\
\text { (High school or above) }\end{array}$ & $\begin{array}{c}-0.34 \\
(-0.44--0.23)\end{array}$ & $<0.001$ & $\begin{array}{c}-0.09 \\
(-0.20-0.02)\end{array}$ & 0.098 \\
\hline Current smoker & $\begin{array}{c}0.20 \\
(0.04-0.36) \\
\end{array}$ & 0.02 & $\begin{array}{c}0.16 \\
(-0.006-0.33) \\
\end{array}$ & 0.059 \\
\hline Current alcohol use & $\begin{array}{c}0.34 \\
(0.12-0.56)\end{array}$ & 0.003 & $\begin{array}{c}0.16 \\
(-0.06-0.37)\end{array}$ & 0.15 \\
\hline Elevated blood pressure & $\begin{array}{c}0.49 \\
(0.38-0.60) \\
\end{array}$ & $<0.001$ & $\begin{array}{c}0.08 \\
(-0.03-0.19) \\
\end{array}$ & 0.18 \\
\hline A low HDL level & $\begin{array}{c}0.40 \\
(0.24-0.57) \\
\end{array}$ & $<0.001$ & $\begin{array}{c}0.26 \\
(0.10-0.41) \\
\end{array}$ & 0.001 \\
\hline Abdominal obesity & $\begin{array}{c}0.80 \\
(0.70-0.90) \\
\end{array}$ & $<0.001$ & $\begin{array}{c}0.57 \\
(0.46-0.68) \\
\end{array}$ & $<0.001$ \\
\hline $\begin{array}{c}\text { An elevated level of blood } \\
\text { glucose }\end{array}$ & $\begin{array}{c}0.55 \\
(0.40-0.69) \\
\end{array}$ & $<0.001$ & $\begin{array}{c}0.19 \\
(-0.15--0.34) \\
\end{array}$ & 0.007 \\
\hline Uric acid & $\begin{array}{c}0.003 \\
(0.002-0.003)\end{array}$ & $<0.001$ & $\begin{array}{c}0.002 \\
(0.001-0.002) \\
\end{array}$ & $<0.001$ \\
\hline ACR & $\begin{array}{c}0.24 \\
(0.18-0.30)\end{array}$ & $<0.001$ & $\begin{array}{c}0.11 \\
(0.04-0.17)\end{array}$ & 0.001 \\
\hline
\end{tabular}

\subsection{Association of Elevated CRP Levels with the Number of Metabolic Syndrome Components}

(Tables 4 and 5)

In the total population, subjects with a higher level of CRP had a greater number of MetS components (Table 4). In the unadjusted model, compared with participants without any components of MetS, relative risks of elevated CRP levels were 2.79 (95\% CI 1.71-4.59, $p<0.001), 4.85$ (95\% CI $3.00-7.84, p<0.001), 6.48$ (95\% CI 3.97-10.58, $p<0.001)$ and 10.62 (95\% CI 6.10-18.50, $p<0.001)$ for subjects with 1, 2, 3, or more than 3 components, respectively. The number of components of MetS was a significant determinant of elevated CRP levels after adjusted for age, sex, current smoking, current alcohol use, education attainment, history of coronary heart disease, history of stroke, and 
physical inactivity. Further adjustment for ACR and uric acid, the number of components of MetS was still significantly associated with elevated CRP levels. In multivariate analysis, relative risks of elevated CRP levels were 2.40 (95\% CI 1.44-3.99, $p=0.001$ ), 3.63 (95\% CI 2.20-5.98, $p<0.001$ ), 4.23 (95\% CI 2.51-7.11, $p<0.001)$ and 6.23 (95\% CI 3.45-11.26, $p<0.001$ ) for subjects with $1,2,3$, or more than 3 components, respectively.

Table 4. Number of metabolic syndrome components present in subjects with different CRP categories.

\begin{tabular}{|c|c|c|c|}
\hline $\begin{array}{l}\text { Number of MetS } \\
\text { components }\end{array}$ & $\begin{array}{c}\text { Group 1 } \\
\text { CRP }<0.5 \mathrm{mg} / \mathrm{L} \\
\mathrm{N}=925\end{array}$ & $\begin{array}{c}\text { Group } 2 \\
1 \mathrm{mg} / \mathrm{L}<\mathrm{CRP}<3 \mathrm{mg} / \mathrm{L} \\
\mathrm{N}=\mathbf{5 5 4}\end{array}$ & $\begin{array}{c}\text { Group } 3 \\
\text { CRP }>3 \mathrm{mg} / \mathrm{L} \\
\mathbf{N}=\mathbf{3 5 5}\end{array}$ \\
\hline 0 component & $281(30.38)$ & $74(13.36)$ & $22(6.20)$ \\
\hline 1 component & $301(32.54)$ & $132(23.83)$ & $75(21.13)$ \\
\hline 2 components & $206(22.27)$ & $161(29.06)$ & $109(30.70)$ \\
\hline 3 components & $110(11.89)$ & $135(24.37)$ & $97(27.32)$ \\
\hline 4 components & $23(2.49)$ & $47(8.48)$ & $41(11.55)$ \\
\hline 5 components & $4(0.43)$ & $5(0.90)$ & $11(3.10)$ \\
\hline
\end{tabular}

Table 5. Association of an elevated CRP level with the number of metabolic syndrome components.

\begin{tabular}{|c|c|c|c|c|c|c|c|c|}
\hline \multirow{2}{*}{$\begin{array}{l}\text { Number of } \\
\text { Component }\end{array}$} & \multicolumn{2}{|c|}{ Model one ${ }^{a}$} & \multirow{2}{*}{$\begin{array}{c}\text { Model two }^{\mathrm{b}} \\
\text { RR }(95 \% \text { CI })\end{array}$} & \multirow[b]{2}{*}{$p$ value } & \multirow{2}{*}{$\begin{array}{l}\text { Model three }^{c} \\
\text { RR (95\% CI) }\end{array}$} & \multicolumn{3}{|c|}{ Model four ${ }^{d}$} \\
\hline & RR $(95 \%$ CI) & $p$ value & & & & $p$ value & RR $(95 \%$ CI) & $p$ value \\
\hline 0 component & Reference & & Reference & & Reference & & Reference & \\
\hline 1 component & $\begin{array}{c}2.79 \\
(1.70,4.59)\end{array}$ & $<0.001$ & $\begin{array}{c}2.48 \\
(1.50,4.11)\end{array}$ & $<0.001$ & $\begin{array}{c}2.40 \\
(1.44,3.98)\end{array}$ & 0.001 & $\begin{array}{c}2.40 \\
(1.44,3.99)\end{array}$ & 0.001 \\
\hline 2 component & $\begin{array}{c}4.85 \\
(3.00,7.84)\end{array}$ & $<0.001$ & $\begin{array}{c}4.19 \\
(2.56,6.85)\end{array}$ & $<0.001$ & $\begin{array}{c}4.02 \\
(2.45,6.60)\end{array}$ & $<0.001$ & $\begin{array}{c}3.63 \\
(2.20,5.98)\end{array}$ & $<0.001$ \\
\hline 3 component & $\begin{array}{c}6.48 \\
(3.97,10.58) \\
\end{array}$ & $<0.001$ & $\begin{array}{c}5.46 \\
(3.30,9.06)\end{array}$ & $<0.001$ & $\begin{array}{c}5.35 \\
(3.22,8.89)\end{array}$ & $<0.001$ & $\begin{array}{c}4.23 \\
(2.51,7.37)\end{array}$ & $<0.001$ \\
\hline $\begin{array}{c}\text { 4-5 } \\
\text { component }\end{array}$ & $\begin{array}{c}10.62 \\
(6.10,18.50)\end{array}$ & $<0.001$ & $\begin{array}{c}8.97 \\
(5.07,15.89)\end{array}$ & $<0.001$ & $\begin{array}{c}8.62 \\
(4.85,15.31)\end{array}$ & $<0.001$ & $\begin{array}{c}6.23 \\
(3.45,11.26)\end{array}$ & $<0.001$ \\
\hline
\end{tabular}

${ }^{a}$ Unadjusted; ${ }^{b}$ Adjusted for age, sex; ${ }^{c}$ Adjusted for age, sex, history of coronary heart disease, history of stroke, current smoker, current alcohol use, physical inactivity, and education attainment; ${ }^{\mathrm{d}}$ Adjusted for age, sex, history of coronary heart disease, history of stroke, current smoker, current alcohol use, physical inactivity, education attainment, uric acid and ACR.

\subsection{AUC and Optimal Cut Points of hs-CRP for MetS}

The AUC of hs-CRP for MetS was 0.6954 (95\% CI, 0.67-0.72). The AUC of hs-CRP for MetS was 0.67 (95\% CI, 0.63-0.71) in men and 0.71 (95\% CI, 0.68-0.74) in women. The optimal cut-off of hs-CRP was $0.92 \mathrm{mg} / \mathrm{L}(74.71 \%-54.06 \%)$ in men and $0.86 \mathrm{mg} / \mathrm{L}(77.26 \%-53.86 \%)$ in women.

\section{Discussion}

In this Chinese population, 50.43\% subjects have a low level of hs-CRP, 30.21\% (554) subjects had an intermediate hs-CRP level and 19.36\% (355) subjects had an elevated hs-CRP level. Among the 
five components of MetS, abdominal obesity, a low level of LDL, and an elevated fasting glucose level are correlated with the level of log-CRP. Age, physical inactivity, ACR and uric acid are also correlated with log-CRP levels. The number of components of MetS is a significant determinant of elevated CRP levels after adjusted for other potential confounders including ACR and uric acid.

Prospective epidemiologic studies indicated that hs-CRP independently predicts the mortality of CVD and CV events [29-33]. The largest of cohorts study is based on 27,939 initially healthy American women [31]. Hypersensitivity CRP not only adds prognostic information to the Framingham Risk Score but also links to MetS [4,34,35] and the incident of type 2 diabetes [33,35]. C-reactive protein plays an important role in the pathogenesis of atherosclerosis [36]. There are several potential mechanics [12]: (1) CRP can bind the oxidized LDL [37], (2) CRP can decrease nitric-oxide production and inhibit angiogenesis [38-40], (3) Synergy between CRP and inflammatory mediators might play a role in the pathogenesis of atherosclerosis [41]. (4) CRP also can activate complement [42].

Because of the evidence, CDC has endorsed measuring CRP in assessing the risk of CVD [14,15]. As we know, there is very limited data on CRP levels in Chinese population. The results based on a population-based cross-sectional survey conducted in Beijing during 2002-2004 indicated that the median and geometric mean concentrations of hs-CRP were $1.00 \mathrm{mg} / \mathrm{L}$ and $0.79 \mathrm{mg} / \mathrm{L}$, respectively. A level of hs-CRP showed an upward trend with increased age $(p<0.05)$ [43]. However, this population could not represent a general Chinese population, because the population aged 45-74 years [43]. In the present study, all adults were included in the analyses. In this Chinese population, the median of hs-CRP is $1.01 \mathrm{mg} / \mathrm{L}$ and $19.47 \%$ subjects have an elevated level of hs-CRP. Compared with American, the prevalence of an elevated level of hs-CRP is lower [40].

The distribution of C-reactive protein (CRP) levels varies significantly between the various ethnic groups. According to the previous studies, we collected data of distribution of CRP in different ethnic groups and listed them in Table $6[3,42,44,45]$. Obesity is associated with the level of CRP. Both BMI and waist circumference are associated with the level of CRP [16]. The difference in BMI between the various race groups might be a potential explanation for the difference in CRP. However, this did not entirely explain CRP differences [45]. Racial difference in CRP is still controversial. In the present study, the median of CRP in the Chinese population is $0.99 \mathrm{mg} / \mathrm{L}$. This is lower than the median of CRP in 357 Asians in the previous study [44], but is higher than that of Janpanese population [3]. Sex-difference in hs-CRP has also been reported [3], but in the present study, the difference in the male and female is not significant. This is similar to the result in the previous study based on a Chinese population [43].

Table 6. Distribution of CRP in different ethnic groups.

\begin{tabular}{cccc}
\hline Reference & Median of CRP & Ethnic Group & Number of Subjects \\
\hline Albert MA, et al [44] & 2.96 & African women & 475 \\
& 2.02 & Caucasian women & 24,455 \\
& 2.06 & Hispanic women & 254 \\
& 1.12 & Asian women & 357 \\
\hline Forouhi NG, et al [45] & 1.35 & Europe & 57 \\
& 0.70 & South Asians & 56 \\
\hline
\end{tabular}


Table 6. Cont.

\begin{tabular}{cccc}
\hline Reference & Median of CRP & Ethnic Group & Number of Subjects \\
\hline Sun JY, et al [42] & 1.00 & Chinese & 1544 \\
\hline Oda E, et al [3] & 0.28 & Japanese men & 1062 \\
& 0.20 & Japanese women & 647 \\
\hline Present study & 0.99 & Chinese & 1834 \\
\hline
\end{tabular}

Previous studies also indicated that hs-CRP is linked to MetS [4,33,34] and the incident of Type 2 diabetes $[33,34]$. However, the associations of hs-CRP of different components of MetS are not consistent. Not all of the components of MetS are correlated with the level of CRP [6,7,40,46-48]. Waist circumference is the main determinant of an elevated level of CRP [7,48]. The level of hs-CRP is increasing with the greater number of components of MetS [2,6]. In the present analysis, the results also support that not all of components of MetS are correlated with hs-CRP. Only abdominal obesity, low LDL levels, and an elevated fasting glucose level are correlated with log-CRP levels. The results also indicated that the number of components of MetS is a significant determinant of elevated CRP levels after adjusted for other potential confounders including ACR and uric acid. Urinary albumin to creatinine ratio [49] and uric acid [50] might be associated with an elevated level of CRP. The present study also supports the review. In the present study, the associations of ACR and uric acid with the level of CRP are independent of other potential confounders including components of MetS.

Prior studies based on Japanese populations indicated that hs-CRP can be used as indicator for MetS. The optimal cutoff is $0.45 \mathrm{mg} / \mathrm{L}$ for men and $0.25 \mathrm{mg} / \mathrm{L}$ for women [3]. In the present analysis, the AUC of hs-CRP for MetS was 0.6954 for men and 0.71 for women. The optimal cut-off of hs-CRP is higher in the Chinese population.

Several limitations of this study should be mentioned. (1) The present analysis was based on the single measurement of level of CRP without repeating tests. This is a major limitation of the present analysis. (2) This is only a cross-sectional study, and the association of CRP with metabolic disorder need to be further explored in the longitudinal study. (3) In this study, we do not have enough data on CVD (only self-reported history), so we did not assess the associations of the level of CRP with CVD. (4) This population is a median population in southern China and is not a national survey, so this population might not represent all Chinese populations. (5) In the study, the ratio of male to female is about $1: 2$. This sample is bias $[16,17]$.

\section{Conclusions}

In this Chinese population, $50.43 \%$ had a low hs-CRP level, $30.21 \%$ subjects had an intermediate hs-CRP level and 19.36\% subjects had an elevated hs-CRP level. Among the five components of MetS, abdominal obesity, low LDL levels, and an elevated fasting glucose level are correlated with log-CRP levels. Uric acid and ACR are also correlated with log-CRP levels. The associations of uric acid and ACR with the level of CRP are independent of other potential confounders including components of MetS. The number of components of MetS is a significant determinant of elevated CRP levels after adjusted for other potential confounders including ACR and uric acid. 


\section{Acknowledgments}

This study was supported by the following Science Foundation: (1) EU FP7 Program, UroSense, 2011; (2) ISN Research Committee grant, 2007; (3) ISN Research Committee grant, 2004; (4) Guangdong Provincial Science and Technique Program (No. 2011B031800386), 2011.

\section{Author Contributions}

Mingxia Sun and Liying Zhang drafted this manuscript. Mingxia Sun conceived this manuscript. Shanying Chen completed the data analysis. Xinyu Liu and Xiaofei Shao involved in the crosssectional study. Hequn Zou is the PI of the study.

\section{Conflicts of Interest}

The authors declare no conflict of interest.

\section{References}

1. Yang, G.; Wang, Y.; Zeng, Y.; Gao, G.F.; Liang, X.; Zhou, M.; Wan, X.; Yu, S.; Jiang, Y.; Naghavi, M.; et al. Rapid health transition in China, 1999-2010: Findings from the Global Burden of Disease Study 2010. Lancet. 2013, 381, 1987-2015.

2. Graham, L.; Atar, D.; Borch-Johnsen, K.; Boysen, G.; Burell, G.; Cifkova, R.; Dallongeville, J.; De Backer, G.; Ebrahim, S.; Gjelsvik, B.; et al. European guidelines on cardiovascular disease prevention in clinical practice: executive summary: Fourth Joint Task Force of the European Society of Cardiology and Other Societies on Cardiovascular Disease Prevention in Clinical Practice (Constituted by representatives of nine societies and by invited experts). Circulation. 2004, 109, 2818-2825.

3. Oda, E.; Kawai, R. Tentative cut point of high-sensitivity C-reactive protein for a component of metabolic syndrome in Japanese. Circ. J. 2009, 73, 755-759.

4. Lim, S.; Lee, H.K.; Kimm, K.C.; Park, C.; Shin, C.; Cho, N.H. C-reactive protein level as an independent risk factor of metabolic syndrome in the Korean population. CRP as risk factor of metabolic syndrome. Diabetes Res. Clin. Pract. 2005, 70, 126-133.

5. Haffner, S.M. The metabolic syndrome: Inflammation, diabetes mellitus, and cardiovascular disease. Am. J. Cardiol. 2006, 97, 3A-11A.

6. Adam, F.M.; Nara, M.G.; Adam, J.M. Fasting insulin, adiponectin, hs-CRP levels, and the components of metabolic syndrome. Acta Med. Indones. 2006, 38, 179-184.

7. Nakamura, H.; Ito, H.; Egami, Y.; Kaji, Y.; Maruyama, T.; Koike, G.; Jingu, S.; Harada, M. Waist circumference is the main determinant of elevated C-reactive protein in metabolic syndrome. Diabetes Res. Clin. Pract. 2008, 79, 330-336.

8. Bo, S.; Rosato, R.; Ciccone, G.; Cambino, R.; Durazzo, M.; Gentile, L.; Cassader, M.; Cavallo-Perin, P.; Pagano, G. What predicts the occurrence of the metabolic syndrome in a population-based cohort of adult healthy subjects? Diabetes Metab. Res. Rev. 2009, 25, 76-82. 
9. Assoumou, H.G.; Barthelemy, J.C.; Garet, M.; Dauphinot, V.; Celle, S.; Pichot, V.; Kossovsky, M.; Gaspoz, J.M.; Roche, F. Increased waist circumference is the component of metabolic syndrome the component of metabolic syndrome the most strongly associated with elevated C-reactive protein in elderly. Metab. Syndr. Relat. Disord. 2011, 9, 281-285.

10. Belfki, H.; Ben Ali, S.; Bougatef, S.; Ben Ahmed, D.; Haddad, N.; Jmal, A.; Abdennebi, M.; Ben Romdhane, H. Relationship of C-reactive protein with components of the metabolic syndrome in a Tunisian population. Eur. I Intern. Med. 2012, 23, e5-e9.

11. Edalat, B.; Sharifi, F.; Badamchizadeh, Z.; Hossein-Nezhad, A.; Larijani, B.; Mirarefin, M.; Fakhrzadeh, H. Association of metabolic syndrome with inflammatory mediators in women with previous gestational diabetes mellitus. J. Diabetes Metab. Disord. 2013, 12, doi:10.1186/ 2251-6581-12-8.

12. Black, S.; Kushner, I.; Samols, D. C-reactive Protein. J. Biol. Chem. 2004, 279, 48487-48490.

13. Pearson, T.A.; Mensah, G.A.; Alexander, R.W.; Anderson, J.L.; Cannon, R.O., 3rd.; Criqui, M.; Fadl, Y.Y.; Fortmann, S.P.; Hong, Y.; Myers, G.L. et al. Markers of inflammation and cardiovascular disease: Application to clinical and public health practice: A statement for healthcare professionals from the Centers for Disease Control and Prevention and the American Heart Association. Circulation 2003, 107, 499-511.

14. Shishehbor, M.H.; Bhatt, D.L.; Topol, E.J. Using C-reactive protein to assess cardiovascular disease risk. Cleve Clin. J. Med. 2003, 70, 634-640.

15. Suzuki, T.; Voeks, J.; Zakai, N.A.; Jenny, M.S.; Brown, T.M.; Safford, M.M.; LeWinter, M.; Howard, G.; Cushman, M. Metabolic syndrome, C-reactive protein, and mortality in U.S. Blacks and Whites: The Reasons for Geographic and Racial Differences in Stroke (REGARDS) study. Diabetes Care. 2014, 37, 2284-2290.

16. Chen, S.Y.; Liu, H.M.; Liu, X.Y.; Li, Y.; Li, M.; Liang, Y.; Shao, X.; Holthöfer, H.; Zou, H.Q Central Obesity, C-reactive Protein and Chronic Kidney Disease: A Community-based Cross-sectional Study in Southern China. Kidney Blood Press Res. 2013, 37, 392-401.

17. Chen, S.Y.; Chen, Y.M.; Liu, X.Y.; Li, M.; Wu, B.D.; Li, Y.; Liang, Y.; Shao, X.; Holthöfer, H.; Zou, H.Q. Association of Insulin Resistance with Chronic Kidney Disease in Non-diabetic Subjects with Normal Weight. Plos One. 2013, 8, doi:10.1371/journal.pone.0074058.

18. Molarius, A.; Seidell, J.C.; Sans, S.; Tuomilehto, J.; Kuulasmaa, K. Waist and hip circumferences, and waist-hip ratio in 19 populations of the WHO MONICA Project. Int. J. Obes. Relat. Metab. Disord. 1999, 23, 116-125.

19. National Cholesterol Education Program (NCEP) Expert Panel on Detection Ea, and Treatment of High Blood Cholesterol in Adults (Adult Treatment Panel III). Third Report of the National Cholesterol Education Program (NCEP) Expert Panel on Detection, Evaluation, and Treatment of High Blood Cholesterol in Adults (Adult Treatment Panel III) final report. Circulation 2002, 106, 3143-3421.

20. IDF Wordwide Definition of the Metabolic Sydrome. Available online: http://www.idf.org/ metabolic-syndrome (accessed on 3 May 2015). 
21. Zhang, W.; Doherty, M.; Bardin, T.; Pascual, E.; Barskova, V.; Conaghan, P.; Gerster, J.; Jacobs, J.; Leeb, B.; Lioté, F.; et al. EULAR evidence based recommendations for gout. Part II: Management. Report of a task force of the EULAR Standing Committee for International Clinical Studies Including Therapeutics (ESCISIT). Ann. Rheum Dis. 2006, 65, 1312-1324.

22. Perez-Ruiz, F.; Liote, F. Lowering serum uric acid levels: What is the optimal target for improving clinical outcomes in gout? Arthritis Rheum 2007, 57, 1324-1328.

23. Howard, B.V.; Lee, E.T.; Cowan, L.D.; Devereux, R.B.; Galloway, J.M.; Go, O.T.; Howard, W.J.; Rhoades, E.R.; Robbins, D.C.; Sievers, M.L.; et al. Rising tide of Cardiovascular disease in American Indians. The Strong Heart Study. Circulation 1999, 99, 2389-2395.

24. National Kidney Foundation. K/DOQI clinical practice guidelines for chronic kidney disease: Evaluation, classification, and stratification. Am. J. Kidney Dis. 2002, 39, S1-S266.

25. Hanley, A.J.; Williams, K.; Gonzalez, C.; D’Agostino, R.B., Jr.; Wagenknecht, L.E.; Stern, M.P.; Haffner, S.M.; San Antonio Heart Study; Mexico City Diabetes Study; Insulin Resistance Atherosclerosis Study. Prediction of type 2 diabetes using simple measures of insulin resistance: Combined results from the San Antonio Heart Study, the Mexico City Diabetes Study, and the Insulin Resistance Atherosclerosis Study. Diabetes 2003, 52, 463-469.

26. Xing, X.Y.; Yang, W.Y.; Yang, Z.J. The diagnostic significance of homeostasis model assessment of insulin resistance in Metabolic Syndrome among subjects with different glucose tolerance (Chinese). Chin. J. Diabetes 2004, 12, 182-186.

27. Hosmer, D.; Lemeshow, S. Applied Logistic Regression, 2nd ed.; John Wiley \& Sons, Inc.: New York, NY, USA, 2000.

28. Zhang, L.Y.; Yuan, Z.Y.; Chen, W.; Chen, S.Y.; Liu. X.Y.; Liang, Y.; Shao, X.Y.; Zou, H.Q Serum Lipid Profiles, Lipid ratios and Chronic Kidney Disease in a Chinese Population. Int. J. Environ. Res. Public Health 2014, 11, 7622-7635.

29. Ridker, P.M.; Hennekens, C.H.; Buring, J.E.; Rifai, N. C-reactive protein and other markers of inflammation in the prediction of cardiovascular disease in women. N. Engl. J. Med. 2000, 342, 836-843.

30. Rost, N.S.; Wolf, P.A.; Kase, C.S.; Kelly-Hayes, M.; Silbershatz, H.; Massaro, J.M.; D’Agostino, R.B.; Franzblau, C.; Wilson, P.W. Plasma concentration of C-reactive protein and risk of ischemic stroke and transient ischemic attack: The Framingham Study. Stroke 2001, 32, 2575-2579.

31. Ridker, P.M.; Rifai, N.; Rose, L.; Buring, J.E.; Cook, N.R. Comparison of C-reactive protein and low-density lipoprotein cholesterol levels in the prediction of first cardiovascular events. N. Engl. J. Med. 2002, 347, 1557-1565.

32. Albert, M.A.; Glynn, R.J.; Ridker, P.M. Plasma concentration of C-reactive protein and the calculated Framingham Coronary Heart Disease Risk Score. Circulation 2003, 108, 161-165.

33. Ridker, P.M.; Buring, J.E.; Cook, N.R.; Rifai, N. C-reactive protein, the metabolic syndrome, and risk of incident cardiovascular events: An 8-year follow-up of 14,719 initially healthy American women. Circulation 2003, 7, 391-397.

34. Festa, A.; D’Agostino, R., Jr.; Howard, G.; Mykkänen, L.; Tracy, R.P.; Haffner, S.M. Chronic subclinical inflammation as part of the insulin resistance syndrome: The Insulin Resistance Atherosclerosis Study (IRAS). Circulation 2000, 102, 42-47. 
35. Pradhan, A.D.; Manson, J.E.; Rifai, N.; Buring, J.E.; Ridker, P.M. C-reactive protein, interleukin-6, and risk of developing type 2 diabetes mellitus. JAMA 2001, 286, 327-334.

36. Jialal, I.; Devaraj, S.; Venugopal, S.K. C-reactive protein: Risk marker or mediator in atherothrombosis? Hypertension 2004, 44, 6-11.

37. Chang, M.K.; Binder, C.J.; Torzewski, M.; Witztum, J.L. C-reactive protein binds to both oxidized LDL and apoptotic cells through recognition of a common ligand: Phosphorylcholine of oxidized phospholipids. Proc. Natl. Acad. Sci. U. S. A. 2002, 99, 13043-13048.

38. Zwaka, T.P.; Hombach, V.; Torzewski, J. C-reactive protein mediated low density lipoprotein uptake by macrophages: Implications for atherosclerosis. Circulation 2001, 103, 1194-1197.

39. Venugopal, S.K.; Devaraj, S.; Yuhanna, I.; Shaul, P.; Jialal, I. Demonstration that C-reactive protein decreases eNOS expression and bioactivity in human aortic endothelial cells. Circulation 2002, 106, 1439-1441.

40. Verma, S.; Wang, C.H.; Li, S.H.; Dumont, A.S.; Fedak, P.W.; Badiwala, M.V.; Dhillon, B.; Weisel, R.D.; Li, R.K.; Mickle, D.A.; et al. A self-fulfilling prophecy: C-Reactive protein attenuates nitric oxide production and inhibits angiogenesis. Circulation 2002, 106, 913-919.

41. Nakagomi, A.; Freedman, S.B.; Geczy, C.L. Interferon-gamma and lipopolysaccharide potentiate monocyte tissue factor induction by Creactive protein: relationship with age, sex, and hormone replacement treatment. Circulation 2000, 101, 1785-1791.

42. Mold, C.; Gewurz, H.; Du Clos, T.W. Regulation of complement activation by C-reactive protein. Immunopharmacology 1999, 42, 23-30.

43. Sun, J.Y.; Zhao, D.; Wang, W.; Liu, J.; Cheng, J.; Liu, J.; Li, Y.; Jia, Y.N. Distributions of high-sensitivity $\mathrm{C}$-reactive protein and its association with metabolic syndrome in population aged 45-74 in Beijing. Chin. J. Epidemiol. 2007, 28, 1155-1158.

44. Albert, M.A.; Glynn, R.J.; Buring, J.; Ridker, P.M. C-reactive protein levels among women of various ethnic groups living in the United States (from the Women's Health Study). Am. J. Cardiol. 2004, 93, 1238-1242.

45. Forouhi, N.G.; Sattar, N.; Mckeigue, P.M. Relation of C-reactive protein to body fat distribution and features of the metabolic syndrome in Europeans and South Asians. Int. J. Obes. Relat. Metab. Disord. 2001, 25, 1327-1331.

46. Lee, I.T.; Huang, C.N.; Lee, W.J.; Lee, H.S.; Sheu, W.H. The association of low-grade inflammation, urinary albumin, and insulin resistance with metabolic syndrome in nondiabetic Taiwanese. Metabolism 2007, 56, 1708-1713.

47. Nakanishi, N.; Shiraishi, T.; Wada, M. Association between fasting glucose and C-reactive protein in a Japanese population: The Minoh study. Diabetes Res. Clin. Pract. 2005, 69, 88-98.

48. Patel, D.A.; Srinivasan, S.R.; Xu, J.H.; Li, S.; Chen, W.; Berenson, G.S. Distribution and metabolic syndrome correlates of plasma C-reactive protein in biracial (black-white) younger adults: The Bogalusa Heart Study. Metabolism 2006, 55, 699-705.

49. Ling, Y.; Li, X.M.; Gao, X. Cross-sectional association of serum C-reactive protein and uric acid with albuminuria in Chinese type 2 diabetic patients. Chin. Med. J. (Engl). 2013, 126, 4023-4029. 
50. De Carvalho Vidigal, F.; de Lima Rosado, L.E.; Paixão Rosado, G.; Lanes Ribeiro Rde, C.; Castro Franceschini Sdo, C. Serum uric acid can predict higher C-reactive protein levels in apparently healthy men. Nutr. Hosp. 2014, 29, 935-940.

(C) 2015 by the authors; licensee MDPI, Basel, Switzerland. This article is an open access article distributed under the terms and conditions of the Creative Commons Attribution license (http://creativecommons.org/licenses/by/4.0/). 